\section{Investment Success}

\section{Building and}

Managing Your Retirement Portfolio

\section{BRASS Program Planning Committee}

Brass Program Planning Committee members: Peter McKay, chair, University of Florida; Ann M. Fiegen, California State University San Marcos; Diane Campbell, Rider University; Greg Fleming, University of Chicago; Mary Gilles, Washington State University; Todd Hines, Princeton University; Suzanne Kaller, Arapahoe Library District; Patricia Kenly, Georgia Institute of Technology, Carissa Phillips, University of Illinois at Urbana/Champaign; Michael Oppenheim, University of California Los Angeles.

BRASS Program Committee Authors: Peter McKay, Business Librarian, University of Florida; Ann M. Fiegen, Librarian for Business, California State University San Marcos; Greg Fleming, Business Reference Librarian, University of Chicago; Suzanne Kaller, Business Librarian, Arapahoe Library District; Patricia Kenly, Business Reference Librarian, Georgia Institute of Technology; Carissa Phillips, Business and Finance Information Librarian, University of Illinois at Urbana-Champaign.
$\mathbf{T}$ he Business Reference and Services Section (BRASS) 2013 Program, "Investment Success: Building and Managing Your Retirement Portfolio" was aimed at librarian's financial education and retirement planning. Two financial professionals, Charles Rotblut and Jeremy Glaser presented investment strategies for retirement planning.

Good personal investment education is important for librarians and library staff. We are an occupational group that is rarely able to access top financial advice. In this program, investment professionals demystified the process and helped library professionals understand essential principles and how to apply them to make better decisions to meet retirement goals. The presentations included a discussion of the common mistakes investors make, why we make them, and how to avoid them. A bibliography of recommended readings accompanies the program summary.

Charles Rotblut, CFA, Vice President with the American Association of Individual Investors was the first speaker. ${ }^{1}$ AAII is a nonprofit organization founded in 1978 with the goal of helping to educate investors on how to manage their portfolios, focusing on all aspects of investing, including security analysis, portfolio management, and withdrawal. Within AAII, Mr. Rotblut is editor of the AAII Journal and authors the weekly AAII Investor Update newsletter. He is also the author of the book Better Good than Lucky: How Savvy Investors Create Fortune with the Risk-Reward Ratio, which was published in $2010 .^{2}$

The overriding message of Mr. Rotblut's presentation was the importance of balancing risk and reward in investing. "The investor should establish an investment strategy to achieve maximum return while accepting a level of volatility that is personally tolerable. The optimal strategy should be one that is sustainable over the long term." To address these issues, Mr. Rotblut offered four steps.

The first step is to "understand the role your mind plays." Mr. Rotblut discussed evidence from the field of behavioral finance suggesting that over time humans have become genetically programmed to be "loss averse" because survival depends upon it. Therefore, most investors focus more on potential losses than on potential profit, feeling the pain of losses more than the pleasure of gains. At the same time, investors tend to be overconfident, always believing that their decisions are the right ones. Figure 1 shows the impact of overconfidence as shown by Harvey in the AAII Journal. ${ }^{3}$ They seek information to support those decisions while disregarding evidence to the contrary or "confirmation bias."

Mr. Rotblut also added that individuals tend to expect 


\section{FROM COMMITTEES OF RUSA}

current conditions to continue into the future or "recency bias." Thus, when the market seems to be trending downward, individuals expect this pattern to continue. He also pointed out that the aging process with its increased risk of dementia can lead to a decline in decision-making ability.

To counteract behavioral influences, Mr. Rotblut discussed the importance of a calm state of mind when making investment decisions. He suggested ignoring daily news about the markets and its gyrations particularly during a period of extreme volatility. However, some risk must be endured for an investment portfolio to achieve returns that outpace the rate of inflation, which should be an investor's goal. That being said, selling an investment should be a last resort move when a particular holding is causing acute anxiety.

To compensate for cognitive decline as we age, Mr. Rotblut suggested that portfolios be simplified, containing only investments that are well understood. An emergency plan should be in place with instructions for someone else to manage the portfolio according to the investor's wishes.

The second step offered by Mr. Rotblut is to be sure that all investment strategies and decisions are in writing. Findings of psychological studies have revealed that individuals tend to make the most rational decisions when those decisions are made ahead of a crisis situation. Criteria for selling an investment should be made in advance to avoid a decision that is emotionally charged. Studies have also shown that the "endowment effect" causes individuals to place more value on a purchase once it has been made thus making it even more difficult to take action to sell. So, having written guidelines in place for selling an investment can remove the emotional component of the decision.

Mr. Rotblut records the reasons he bought an investment as well as the conditions under which he would sell. By recording news and fundamental data about an investment, he builds a story to illuminate any negative trends. He also reviews research notes during the course of a year when evaluating different investment options.

For the third step, Mr. Rotblut discussed developing a long-term allocation strategy. An appropriate asset allocation should be based on an investor's age, health, and wealth. All asset allocation models are based on the concept of diversification or the practice of holding a basket of different asset classes within a portfolio. With correlations among asset classes in mind, the investor improves the likelihood of being in the right asset class at the right time; thus creating balance among investments, reducing risk, and ideally creating greater wealth. Diversification can also be achieved across portfolios of multiple investors within a family, and with careful planning, household taxes can be minimized.

The portfolio should be rebalanced periodically to return its allocation to the investor's original plan. Mr. Rotblut referred to the Vanguard Group's recommendation of rebalancing either annually or semiannually once the portfolio has veered five percentage points or more. ${ }^{4}$ Results of his own analysis showed that rebalancing and remaining invested in stocks during periods of market volatility can result in substantial returns, while

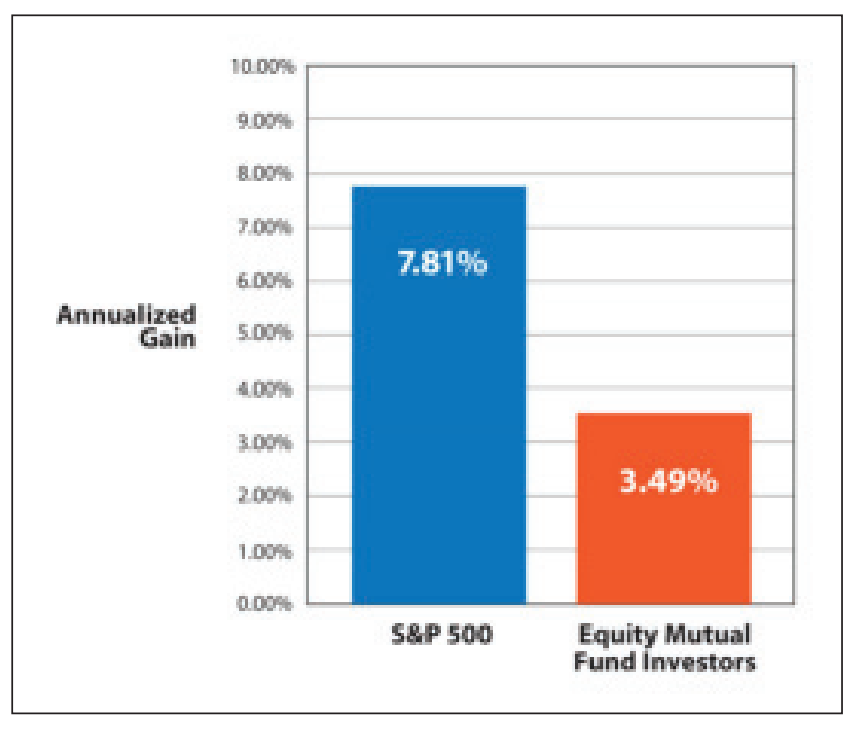

Figure 1. The Impact of Overconfidence (Source: "How Investors Miss Big Profits," Louis Harvey, AAll Journal, October 2012, data from 1988 to 2011)

panic selling during a crisis may result in losses never to be recouped. Although rebalancing may not prevent investors from losing money, the data show that the losses will be lessened.

The fourth and final step presented is to "select good funds." Rather than focus on maximizing returns, focus on the selection of asset classes and then identify the best funds for each class. Choose funds with the lowest expenses and compare long-term returns of similar investments ("apples to apples"). Mr. Rotblut suggested that investors commit to a long term investment horizon. Fund prospectuses should be reviewed year-over-year for changes that may have occurred such as new investment managers or changes in investment objectives.

Mr. Rotblut concluded his presentation by encouraging the audience members to be active investors. As he said "buying and holding is a very good strategy; but buying and forgetting is a lousy strategy." Investors should seek to manage their portfolios in a professional manner, recognizing their own emotional tendencies and past mistakes, and setting up rational systems to govern future buy and sell decisions.

Jeremy Glaser is markets editor for Morningstar.com, responsible for directing all stock market coverage for Morningstar's website for individual investors. Before assuming his current role in 2009, he was a senior equity analyst for Morningstar, covering the leisure, hospitality, and gaming sectors. He joined Morningstar in 2006. Mr. Glaser holds a bachelor's degree in economics from the University of Chicago. The focus of Mr. Glaser's presentation was money strategies for the phases in one's life, and included sample investment portfolios and asset allocations.

In the first phase, the "young accumulators" (people in their twenties), should strive to get out of debt (for example, from a student loan), and then stay out of consumer debt. 


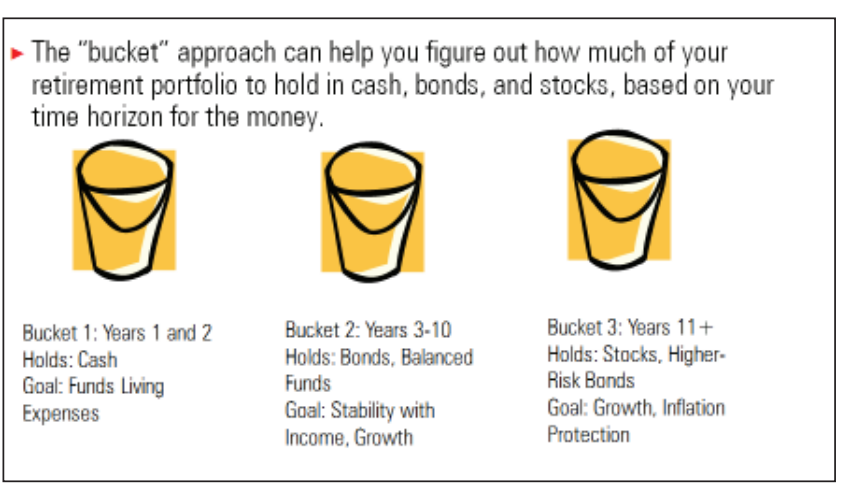

Figure 2. Segment Portfolio by Time Horizon (Source: Christine Benz and Adam Zoll, "Investing Well at Every Life Stage", MoneySmart Week April 24, 2013, accessed August 13, 2013, http://news.morningstar.com/pdfs/moneysmart week042413.pdf)

Mr. Glaser recommended even at a young age, kick-starting a retirement plan as well as saving for near-term goals such as a down payment for a house.

Those in their thirties and forties should maximize contributions to retirement plans, and retain an emphasis on long-term growth through stocks. Savings are also important for children's college funds in particular. At this stage in investing, saving in taxable accounts is recommended because it provides flexibility in withdrawals in retirement.

Mr. Glaser said that pre-retirees (people in their fifties and sixties) need to save very aggressively for retirement by following these steps. Pay off all debt, even "good" debt such as a mortgage. Those intending to stay in their homes should consider prepaying their mortgage. Gradually reduce risk in one's portfolio. Start thinking about retirement needs-specifically, month-to-month income. Formulate a long-term care plan as well as an estate plan. This over-50 age group can take advantage of catch-up contributions to 401(k), 403(b), and 457 accounts, which is particularly useful if an employer does a matching contribution. Mr. Glazer indicated that preretirees should assess their retirement readiness by looking at online calculators. He referred the audience to the T. Rowe Price Retirement Income Calculator and the Fidelity Retirement Quick Check. ${ }^{5}$

Individuals nearing retirement should have a Social Security strategy as well as a retirement date strategy in place. He noted that if you can delay retirement up to age 70 , you receive 8 percent more for every year after "full" social security eligibility up to the age 70 . He recommended using the Social Security Administration's Retirement Estimator and the T. Rowe Price Social Security Benefits Evaluator. ${ }^{6}$

He cautioned that to have the same lifestyle in retirement, you will need about 80 percent of your current income. When you consider your income needs, note that you will no longer have some costs (commuting, parking); other costs will be significantly reduced (no need to buy new clothes as often, for example) but medical expenses may go up. Remember that in retirement, you will no longer have deductions for Social Security nor your pension.

Mr. Glaser explained the " 4 percent rule"-the amount that can be safely withdrawn annually from a retirement portfolio to meet income needs while preserving capital for today's longer life expectancies. For example, a retired couple who wants $\$ 60,000$ per year, assuming $\$ 30,000 / y$ r. from Social Security, would withdraw $\$ 32,000$ /year from a portfolio of $\$ 800,000$ for a total annual income of $\$ 62,000$.

Retirees in their 60s and 70s should continue to reduce risk in their investment portfolios. The asset mix should gradually be shifted to higher percentages of cash and bonds. He gave the following example based on Morningstar's Lifetime Allocation Indexes: U.S. Stocks: 31 percent; Non-U.S. Stocks: 10 percent; U.S. Bonds: 34 percent; Non-U.S. Bonds: 5 percent; Treasury Inflation-Protected Securities (TIPS): 12 percent; Commodities: 6 percent; Cash: 3 percent. TIPS help ensure purchasing power. ${ }^{7}$

While long-term care insurance is useful, it can be prohibitively expensive. Mr. Glaser's recommendation is to buy a minimal amount of coverage, and to opt for less of an inflation benefit (i.e., 3 percent rather than 5 percent). The average long-term care stay is 18 months. Having a will as well as an advance directive in place is an important part of your overall plan. ${ }^{8}$ Have your power of attorney in place for both medical and financial needs.

The "Bucket" approach is gaining in popularity as a method of segmenting a retiree's portfolio by time horizon. The bucketing approach was originally developed by Harold Evensky and a more recent variation is described by Christine Benz in a 2012 news article: A Sample Retirement Portfolio Using the Bucket Approach. " "Bucketing" makes it easier to decide on what to withdraw. For Years 1-2 in retirement (Bucket 1 ), the goal is to fund living expenses, and so cash (and cash equivalents such as CDs) are important. In Bucket 2, for retirement years 3-10, the goal is stability with income growth, and so bonds and balanced funds are important. Bucket 3, for retirement years 11 and later, the goal is growth, and so stocks (as well as higher-risk bonds) are important.

An example of the "bucketing" approach is a $\$ 750,000$ portfolio in three parts, or "buckets":

- Bucket $1=\$ 60,000$; Bucket $2=\$ 240,000$; Bucket $3=$ $\$ 450,000$. Total annual income needed from investments: $\$ 30,000$.

- Bucket 1 portfolio is $\$ 60,000$ in cash (and CDs, money market accounts, etc.)

- Bucket 2 portfolio is $\$ 240,000$ and a sample would be:

- $\$ 65,000$ Short-Term Bond Fund

- \$75,000 Intermediate-Term Bond Fund

- \$50,000 Inflation-Protected Bond

- \$50,000 Moderate Allocation mixed bond and equity fund

- Bucket 3 portfolio is $\$ 450,000$ and a sample would be:

- \$200,000 Large Blend Equity Fund

- $\$ 100,000$ Foreign Large Blend equity fund

- \$50,000 Large Blend Index fund 


\section{FROM COMMITTEES OF RUSA}

- $\$ 65,000$ Multisector Bond fund

- \$35,000 Commodities Broad Basket fund

As a retiree pulls income from a portfolio, liquidating the investments in a tax-efficient manner is important to an overall strategy; properly sequencing them can result in big savings over time. Mr. Glaser recommended that in most situations one would liquidate taxable assets first followed by tax sheltered assets and lastly a Roth account. A rule of thumb is to withdraw 3 percent at the beginning of retirement and increase to 4 percent. He cautioned to regularly revisit and adjust the withdrawal rule based on factors of risk tolerance and market performance, asset allocation, age, increasing significant inflation, and unplanned expenses.

\section{SUMMARY}

This program was aimed at library professionals managing their own life savings and retirement planning. As the country comes out of a recession the program committee's purpose was to offer library professionals a look at why one finds it hard to make investment decisions, to offer guidance from financial professionals and to encourage attendees and readers of this column to study this advice and the list of references to evaluate our own financial health.

As a profession business librarians follow the Guidelines for Business Information Responses. ${ }^{10}$ The material presented here and the list of sources may serve as additional sources for investment and financial planning inquires of library users. The program presentation will be available via the BRASS website later in the year.

\section{SELECTED BIBLIOGRAPHY}

2013 Investment Company Fact book: A Review of Trends and Activities in the US Investment Company industry. Investment Company Institute. 53rd ed., 2013. Accessed 8/1/2013. www.icifactbook.org.

AAII: The American Association of Individual Investors. Accessed 8/1/2013. http://www.aaii.com. The website offers a mix of free resources and member benefits. The AAII Investor Update is a free weekly email newsletter edited by Charles Rotblut. It covers investment education and direction, stock and fund investing, asset allocation, portfolio management and more. AAII Asset Allocation Models and articles provide guidelines for selecting the right combination of stocks, bonds and mutual funds by age and risk tolerance.

Ariely, Dan. Predictably Irrational: The Hidden Forces That Shape Our Decisions. (New York: Harper, 2008).

"FINRA Investors." Financial Independent Regulatory Authority. Accessed August 13, 2013. www.finra.org/Investors/index.htm.
"Investor Psychology" Kiplinger. July 9, 2012. Accessed August 13, 2013. http://www.kiplinger.com/fronts/specialreport/investor-psychology/index.html.

Kahneman, Daniel. Thinking Fast and Slow. New York: Farrar, 2011.

Kahneman, Daniel and Amos Tversky. "Prospect Theory: An Analysis of Decision Under Risk," Econometrica, 47, no. 2 (1979): 263-91.

Morningstar. Ibbotson SBBI 2013 Classic Yearbook: Market results for Stocks, Bonds, Bills, and Inflation 1926-2012. Chicago, IL: Morningstar, 2013. See Chapter 15 "Lifecycle Investing."

Statman, Meir. What Investors Really Want. New York: McGraw-Hill, 2011.

\section{References}

1. AAII: The American Association of Individual Investors, accessed August 1, 2013, www.aaii.com.

2. Charles Rotblut, Better Good Than Lucky: How Savvy Investors Create Fortune with the Risk-Reward Ratio (Cedar Falls, IA: W\&A Publishing, 2010)

3. Louis Harvey, "How Investors Miss Big Profits," AAII Journal, October 12, 2012

4. "Stay on Track for Rebalancing," Vanguard Group, accessed August 12, 2013, https://retirementplans.vanguard.com/VGApp/ pe/pubeducation/retirement/Buildingwealth/progress/StayStable Rebalance.jsf.

5. "Retirement Income Calculator," T. Rowe Price, accessed August 1, 2013,www3.troweprice.com/ric/ricweb/public/ric.do; "Retirement Quick Check" Fidelity, accessed August 1, 2013, www.fidelity.com/ calculators-tools/retirement-quick-check.

6. "Retirement Estimator," Social Security Administration, accessed August 1, 2013, www.ssa.gov/estimator; "Social Security Benefits Calculator," T. Rowe Price, accessed August 1, 2013, http://individual.trowerice.com/public/Retail/Retirement/ Social-Security-Tool?van=socialsecurity.

7. "Investing for the Long Run: Strategies and Solutions to Help You Shape Up Your Personal Finances," Morningstar, accessed August 13, 2013, http://library.morningstar.com/mkt/investing for_the_long_run.pdf. This is a free, 119-page guide to investing covering personal financial planning and investing throughout the lifecycle.

8. "Advanced Directives," MedlinePlus, accessed August 12, 2013, www.nlm.nih.gov/medlineplus/advancedirectives.html

9. Christine Benz, "A Sample Retirement Portfolio Using a Bucket Approach," Morningstar, August 30, 2012, accessed August 13, 2013, http://news.morningstar.com/articlenet/article.aspx?id $=566257$

10. "Guidelines for Business Information Sources," American Library Association, Reference and User Services Division, accessed August 13, 2013, www.ala.org/rusa/resources/guidelines/business. 